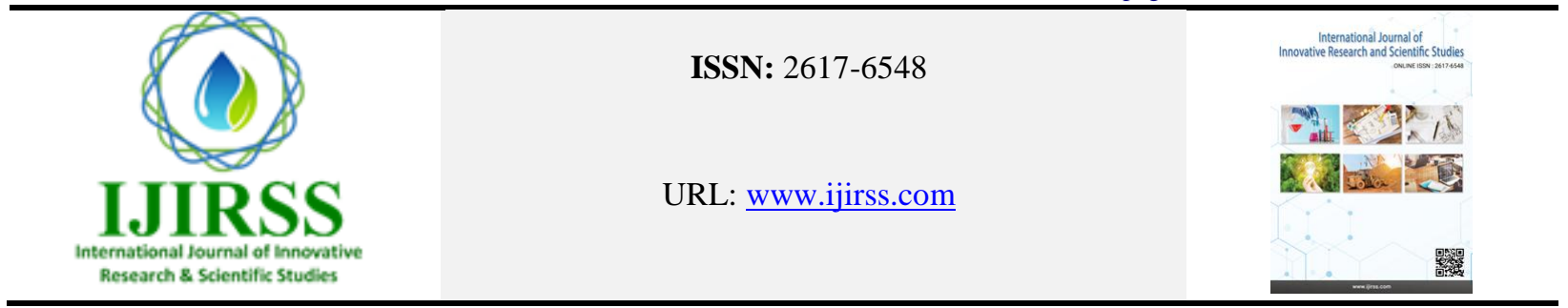

\title{
Biogas Production from Napier Grass and Cattle Slurry Using a Green Energy Technology
}

\author{
Vannasinh Souvannasouk ${ }^{1,2}$, Ming-yan Shen ${ }^{3,4}$, Marlen Trejo ${ }^{5,6}$, Prakash Bhuyar $^{5,6,} *$ \\ ${ }^{1}$ Master Program of Agricultural Economics Natural Resource and Environmental, Maejo University, Chiang Mai 50290, Thailand \\ ${ }^{2}$ Faculty of Economics and Management, Champasak University, Champasak 16120, Lao PDR \\ ${ }^{3}$ Master's Program of Green Energy Science and Technology, Feng Chia University, Taichung 40724, Taiwan \\ ${ }^{4}$ Asian Development College for Community Economy and Technology (adiCET), Chiang Mai Rajabhat University, Chiang Mai 50180, \\ Thailand \\ ${ }^{5}$ School of Renewable Energy, Maejo University, Chiang Mai 50290, Thailand \\ ${ }^{6}$ Sustainable Resources and Sustainable Engineering Research Lab, Maejo University, Chiang Mai 50290, Thailand \\ *Corresponding author: Prakash Bhuyar (prasadmbhuyar@gmail.com)
}

\begin{abstract}
The use of alternative biomass sources that are not competitive with food production is intended for sustainable management in biogas production through anaerobic digestion. This study investigates the Napier grass and cattle slurrybased biogas production application that could be applied more cost-effectively more sustainable production biogas. The laboratory-based biogas plant and a biogas plant in practice revealed that the results from the laboratory experiments were realistic and transferable into practice. The effect of feedstock screening on the biogas yield of Napier grass and cattle slurry was evaluated in batch digesters under mesophilic conditions. Moreover, highest methane content was reached $64.4 \%$. The biogas from the co-digestion of Napier grass and cow farm slurry containing the higher calorific value was $25.69 \mathrm{MJ} / \mathrm{m} 3$, and the lower calorific value was $23.14 \mathrm{MJ} / \mathrm{m} 3$. The results demonstrated that combining Napier grass with common cow farm slurry can accelerate the reaction, increase efficiency, and increase methane content. Therefore, the codigestion of Napier grass and cow farm slurry was a promising method for increasing biogas production.
\end{abstract}

Keywords: Napier Grass, Cattle Slurry, Co-digestion, Biogas Production, Green Energy.

DOI: $10.53894 /$ ijirss.v4i3.74

Funding: This study received no specific financial support.

History: Received: 19 April 2021/Revised: 24 May 2021/Accepted: 8 June 2021/Published: 18 June 2021

Licensed: This work is licensed under a Creative Commons Attribution 4.0 License $(\mathrm{cc}) \mathrm{EY}$

Acknowledgement: Authors thanks our research supervisors Dr. Rameshprabu Ramaraj and Dr. Yuwalee Unpaprom, Maejo University, Chiang Mai. Furthermore, acknowledge the following organizations for providing facilities including Energy Research Center (ERC), School of Renewable Energy, Program in Biotechnology (Faculty of Science) and Swine farm (Animal Science and Technology), Maejo University, Chiang Mai, Thailand.

Competing Interests: The authors declare that they have no conflict of interests.

Transparency: The authors confirm that the manuscript is an honest, accurate, and transparent account of the study was reported; that no vital features of the study have been omitted; and that any discrepancies from the study as planned have been explained.

Ethical: This study follows all ethical practices during writing.

\section{Introduction}

Coal, petroleum crude oil, and natural gas are all used extensively in the world's commodity markets as energy sources, fuels, and chemicals. However, since it takes millions of years for fossil fuels to form globally, their supplies are limited 
and subject to depletion when used up [1-3]. Biomethane's benefits, such as reduced emissions and long-term sustainability, are frequently mentioned. The only other naturally occurring, energy-containing carbon resource known that is large enough to be used as a substitute for fossil fuels is biomass [4]. Biogas reduces greenhouse gas emissions while also improving protection because it can disperse electricity. The approach is better for the environment because it uses agricultural and industrial byproducts rather than conventional methods and uses biomass-generated power at a lower cost. Although the waste digestate produced by anaerobic decomposition is excellent, digestate is uncommon in agriculture due to the lack of air delivery [5]. Biomethane, which can be used for both power and distribution and is made from biogas, is easy to scale and allows for decentralized use of biomass. Data on Europe: livestock waste, crop residues, sewage, and Municipal Solid Waste (MSW)sludge are available. While the United States (U.S.) has few specific specifications, its manure and sludge shortage are restraints. The three categories that make up the total biogas capacity include animal waste, municipal waste, and organic waste (i.e., manure, agriculture residues and energy crops) [4]. One of the major greenhouse gases affecting the redistribution of solar energy in the Earth's atmosphere is methane. About $20 \%$ of its anthropogenic emissions are produced by agriculture and, in particular, by livestock. The most significant volumes of greenhouse gases are emitted during intestinal fermentation of farm animals (about 40\%) and synthetic fertilizers in crop production (more than $13 \%$ ), and these figures are increasing every year.

Greenhouse gases also occur during biological processes: agricultural generates the methane from total emissions are higher [6]. Mainly, methane emissions are produced by cattle and manure storage systems - particularly animal manure; and systems for collecting liquid manure, which is used by the vast majority of pig farms in the country, have higher methane emission factors. Livestock waste is also a source of other gases that, at high concentrations, can cause poisoning or explosions. Organic waste production involves high costs for agricultural enterprises and the food industry [7]. For the collection of wastewater, agrarian enterprises must build huge containers filled with wastewater and stored them for six months or more. So also considers further growth of livestock, pigs, and poultry - hence, the volume of waste could be increased, and environmental protection might be. For this reason, in recent years, there has been a growing awareness of the need for stricter waste management controls.

All non-fossil organic materials with a chemical energy content are classified as biomass. In addition, there is virgin biomass, such as urban solid waste, municipal biosolids (sewage), animal wastes (manure), forestry and agricultural residues, and certain forms of industrial wastes. Biomass, unlike fossil fuels, is environmentally friendly since it takes only a short time to replace the energy source [8]. On a global scale, the energy capacity of biomass is immense. Standing biomass fuel, or renewable, above-ground biomass that could be harvested and used as an energy resource, is expected to be 100 times the global annual energy consumption.

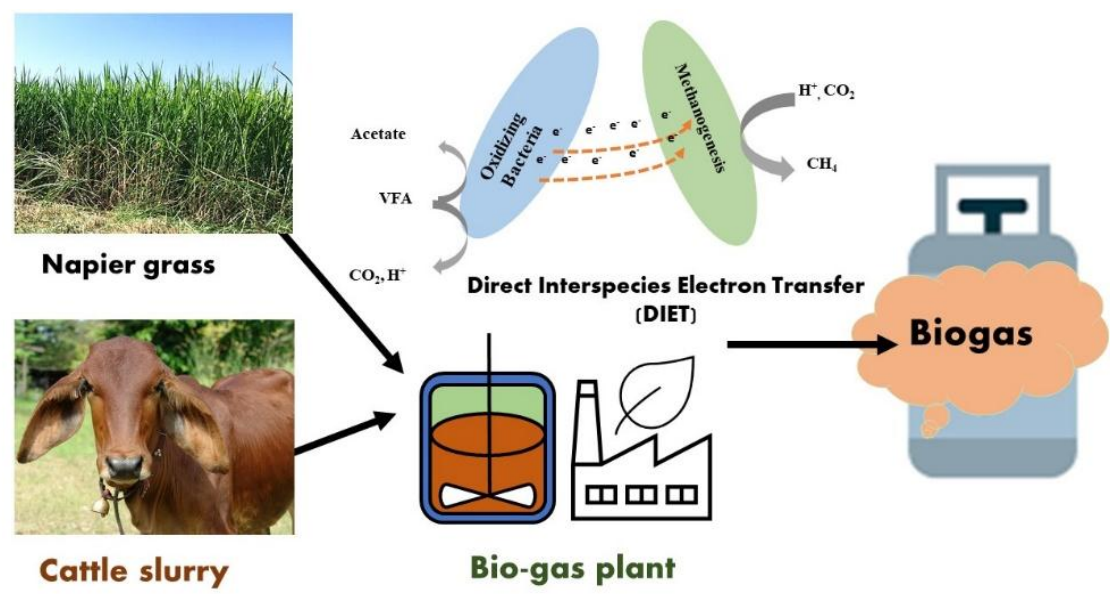

Figure-1.

A schematic overview of the biogas production process from Napier grass and cattle slurry.

The technology for producing biogas has been around since the early 1900s, when it was first used to stabilize organic sludge produced during domestic sewage treatment [9]. It has also been used in India since 1923 and in China for nearly 72 years. This technology has not reached its full potential in the last 50-60 years for various reasons. However, interest in this technology has recently increased, particularly in developing countries. Governments in Asia, including China, India, Nepal, Thailand, and Lao etc., have shown varying degrees of interest in biogas technology. More than $90 \%$ of existing biogas plants are family-sized, with the remainder being farm or industrial-scale [4, 5].

As a biogas feedstock, lignocellulose biomass, such as energy crops, forestry residues, and farm rubble, is gaining popularity. This is a long-term and valuable resource [10]. Anaerobic digestion (AD) is a biogas extraction technique from lignocellulosic biomass that is thought to be a safe way to use biomass. In the absence of oxygen, anaerobic digestion (AD) is a microbial process that breaks down complex organic molecules such as carbohydrates, proteins, and lipids into methane and carbon dioxide [11]. Methane, with a calorific value of $50 \mathrm{~kJ} / \mathrm{g}$, can be used as a renewable energy source. Perennial grasses are an excellent source of lignocellulosic biomass for biogas production because they are easy to grow, harvest, and process and are available all year. Several perennial grasses, including para, ruzi, guinea, and Napier grass, can be used as biogas feedstock in Thailand. Napier grass is the most valuable of these grasses, producing 75 tons of biomass 
per hectare per year. In addition, several studies have found that co-digestion generates more biogas than mono-digestion $[12,13]$. This study overview and concept were presented in Figure 1. Present study aimed for biogas production with the co-digestion of Napier grass with cattle slurry was evaluated in this study during the AD processes for biogas production.

\section{Materials and Methods}

\subsection{Feedstocks preparation}

Fresh Napier grass was harvested from a cattle feed growing field on the Faculty of Animal Science and Technology's experimental farm in Chiang Mai, Thailand. The biomass was then delivered to Maejo University's Energy Research Center. Stones, bedding, forage grasses, and other impurities in Napiergrass were removed after it was collected. Before being used, the napiergrass was air-dried and then cut into $10 \mathrm{~mm}$ fragments using a grass crusher unit. Next, the Napier grass samples were crushed and sieved with mesh before being dried in the open air. Traditional cattle home farming in Maefake village, near Maejo University, provided the fresh cattle slurry (cow farm slurry) with manure (Figure 2). Finally, the inoculum was obtained from a mesophilic biogas digester with a 1:1 ratio of Napiergrass and cattle slurry as substrates in the Energy Research Center-Maejo University (MJU).

The lignin and hemicellulose in lignocellulosic biomass are extracted during pretreatment, leaving only cellulose (glucan) in the solid. For example, a chemical pretreatment effectively hydrolyzes hemicellulose, while an alkaline solution pretreatment dissolves lignin from Napier grass. Therefore, the lignin removal rate can be improved by adding alkaline pretreatment to the solid fraction that remains after the diluted acid pretreatment. However, previous studies have focused on individual pretreatment methods of lignocellulosic biomass [12, 14]. In this study, prepared Napier grass biomass was treated with $2 \%(\mathrm{NaOH})$. The biomass was incubated at room temperature for two days with 2 percent $\mathrm{NaOH}(\mathrm{w} / \mathrm{v})$, during which the biomass (insoluble fraction) was collected and washed with tap water until the $\mathrm{pH}$ was neutral. The pretreated biomass was placed in sealed plastic bags at $4^{\circ} \mathrm{C}$ after being dehydrated to remove free water.

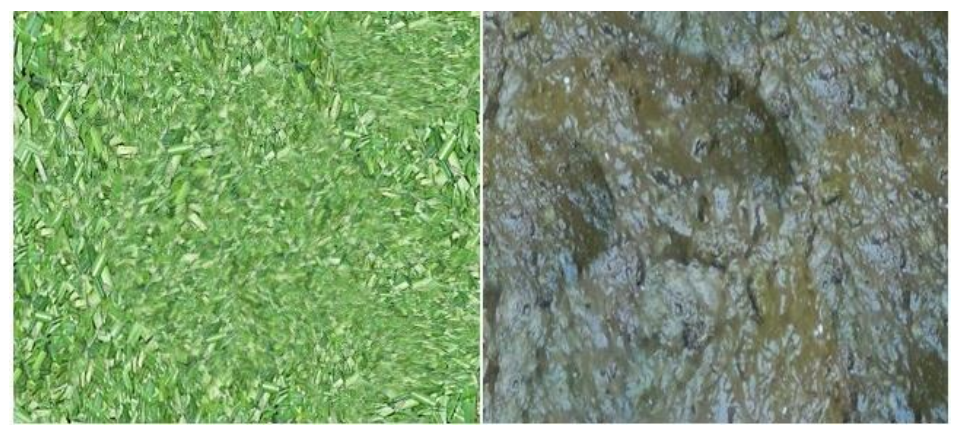

Figure-2.

Feedstocks preparations: Napier grass and cow farm slurry.

\subsection{Determination test of biogas components}

A batch $\mathrm{AD}$ test was conducted using $1000 \mathrm{~mL}$ duran laboratory bottles (working volume: $700 \mathrm{~mL}$ ) as reactors to evaluate the biogas components. The substrate weight ratio is $1: 1$, and the inoculum volume was $100 \mathrm{ml}$. For 45 days, both reactors were held at $37 \pm 2^{\circ} \mathrm{C}$ in a constant temperature water bath (Figure 3). Methods for water displacement and gas analyzer were employed to collect and analyze the biogas production and components, respectively [9, 11].

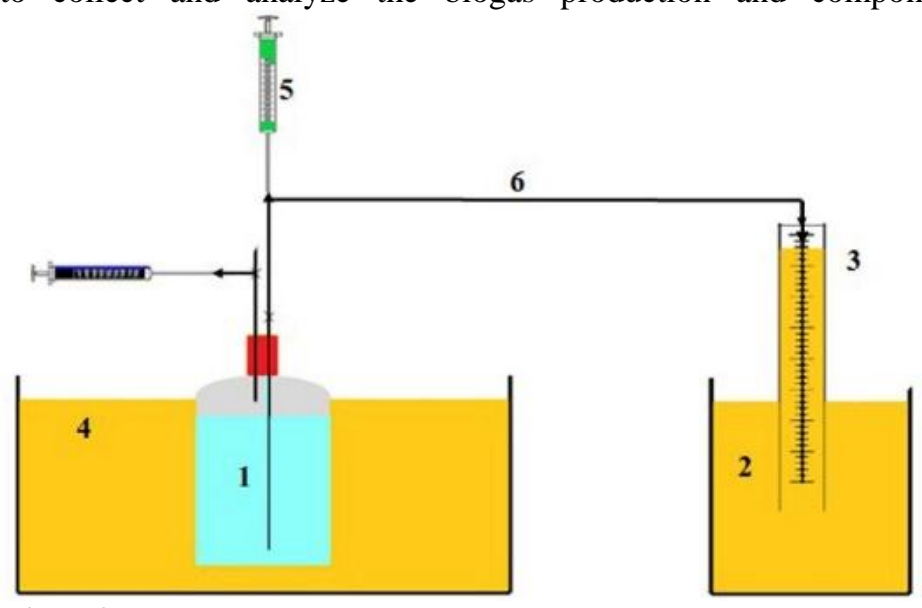

Figure-3.

Biogas batch system (1. fermenter, 2. mini water bath, 3. gas holder, 4. thermostatic water bath, 5. volve, 6. gas transfer tube).

\subsection{Analytical methods}

Total solids (TS) and volatile solids (VS), pH, were measured according to standard methods [15] and the contents of lignin, hemicellulose, and cellulose were determined according to the procedures proposed by Soest, et al. [16]. 


\subsection{Statistical analysis}

All analytical reports were double-checked at least triplicate. The mean and standard deviation of various parameters were calculated. Microsoft Excel 2003 for Windows was used to examine the standard deviations.

\section{Results and Discussion}

\subsection{Napier Grass New Energy Crops: Opportunities and Importance}

Napier grass (Pennisetum purpureum Schum.) is a fast-growing perennial grass native to Sub-Saharan Africa that is widely cultivated throughout the world's tropical and subtropical regions [17]. It is a versatile forage crop that is mainly used to feed cattle in cut-and-carry systems. A moderate level of genetic variation was discovered in a small selection of Napier grasses during characterization and diversity studies, highlighting the availability of some good agronomic traits, exceptionally high biomass production [18]. Napier grass can accumulate more than $60 \mathrm{Mg} / \mathrm{year}$ of dry matter when supplied with sufficient $\mathrm{N}$ and moisture and subjected to proper growing conditions, especially during the active growing season. In total, that is, the annual yield of $40 \mathrm{Mg}$ dry matter from each hectare of forest annually [14]. Therefore, there are strong arguments for this type of grass, especially given its reputation for producing an extremely high milk and protein yield as a primary fodder crop for cattle. Besides the plants with high fiber production yields, besides dry matter, bioenergy requires quality characteristics, including high-fiber yields and low water content.

Table-1.

Physicochemical characteristics of feedstocks.

\begin{tabular}{l|c|c|c}
\hline Parameter & Napier grass & Cow farm slurry & Inoculum \\
\hline Moisture content (\%) & $88.43 \pm 1.43$ & $79.78 \pm 1.77$ & - \\
\hline Ash Content (\%) & $29.88 \pm 0.51$ & $28.59 \pm 1.63$ & - \\
\hline $\mathrm{pH}$ & $4.88 \pm 0.24$ & $7.9 \pm 0.58$ & $6.45 \pm 1.11$ \\
\hline Total Solids (\%) & $89.92 \pm 0.77$ & $29.23 \pm 0.19$ & $5.04 \pm 0.11$ \\
\hline Volatile Solid (\%) & $85.72 \pm 0.13$ & $20.79 \pm 0.89$ & $4.51 \pm 0.05$ \\
\hline Crude Protein (\%) & $11.65 \pm 0.01$ & $16.40 \pm 1.45$ & - \\
\hline Crude Fat (\%) & $3.30 \pm 0.58$ & $5.98 \pm 1.78$ & - \\
\hline Cellulose (\%) & $40.05 \pm 0.12$ & $17.71 \pm 0.33$ & - \\
\hline Hemicellulose (\%) & $26.23 \pm 0.45$ & $25.96 \pm 1.48$ & - \\
\hline Lignin (\%) & $24.11 \pm 0.17$ & $5.93 \pm 1.31$ & - \\
\hline Total Sugar (\%) & $46.68 \pm 1.48$ & $51.97 \pm 0.22$ & $35.99 \pm 0.11$ \\
\hline Total Carbon (\%) & $38.26 \pm 0.25$ & $39.80 \pm 1.33$ & $3.35 \pm 0.05$ \\
\hline Total Nitrogen (\%) & $2.15 \pm 0.06$ & $2.68 \pm 0.72$ & $10.74 \pm 0.12$ \\
\hline C/N & $17.83 \pm 1.16$ & $14.85 \pm 0.03$ & - \\
\hline
\end{tabular}

According to data collected from experiments show on Table 1, the average annual dry matter production of Napier grass in non-fertile soils is about 30 metric tons per hectare, with suitable amounts of lignin in the fuel. Compared to common protein sources, the proteins provided by Napier grass genetic material production seeds were found to be reduced to average levels [18]. Although biomass production was only slightly lower than in the fertilized environment, yields remained high compared to previous levels. Thus, it also improves the suitability of biomass for energy production, with a two-year yield per year. Physicochemical characteristics of feedstocks were presented in Table 1.

\subsection{Slurry Manure Utilization in a Cow Farm Is a New Concept}

Agricultural concerns like greenhouse gases seeping into land and water have caused widespread health problems for humans and livestock, decreasing the spread of animal manure. Animal wastes could lead the land- and water-spreading results in greenhouse gas emissions and human and animal sickness, spreading animal and environmental pollution. Animals and crop excrement wastewater can be used to return cows, horses, and sheep to their liquid state, and so on. Slurry and manure have traditionally been applied to the soil. Sources of water and air and contamination cannot be considered at the moment. The rivers entering the body have wiped out fish and marine life. Eutrophication in shallow bodies of water and lakes can harm biotic systems by causing algal blooms and increased solid loading. A rise in the emission of ammonia gases from land and animals is believed to cause increased soil pollution. A daily production cow requires roughly 435 gallons of water (about $113 \mathrm{~L}$ for drinking and the rest for flushing manure alleys) [19]. This estimate may be underestimated because the water for animal or human drinking water is not factored in. in the best interest of the environment. To properly dispose of and/or utilize cattle manure, this waste stream must be characterized in order to assess its value as a feedstock for energy production. Furthermore, the growing global population and food demand have favored cattle production operations, necessitating selecting proper manure disposal methods [20]. As a result, various waste 
management solutions have been investigated to replace the traditional spread of manure onto soils in order to address this major waste problem. As a result, this paper investigates biochemical and thermochemical processes and existing operational practices for reducing solids during electricity processing and the potential for upgrading biogas for transportation and heating.

\subsection{Anaerobic Digestion}

Because of their high biogas yield per tonne of fresh matter, the use of dedicated energy crops in anaerobic co-digestion systems becomes appealing; additionally, they can achieve adequate carbon to nitrogen ratios (C:N). The biogas inventory data was presented in line with previous research that used lab-scale experiments to assess biogas capacity. The anaerobic digestion process can generate biogas from a wide range of organic substrates. However, most biogas research involves codigesting various forms of agro-industrial wastes with manure [21, 22]. As a result, agricultural biomasses for biogas processing have grown in popularity over the last few years. In this study, Napier grass and cow farm slurry was used to apply a green energy technology for biogas production. Animal manure and energy crops are the most energy-dense substrates. Although livestock effluent has a low methane yield, the large amount of manure produced allows for a high annual methane output. Energy crops have a high energy density, fast kinetics, and a high output capacity [23, 24].

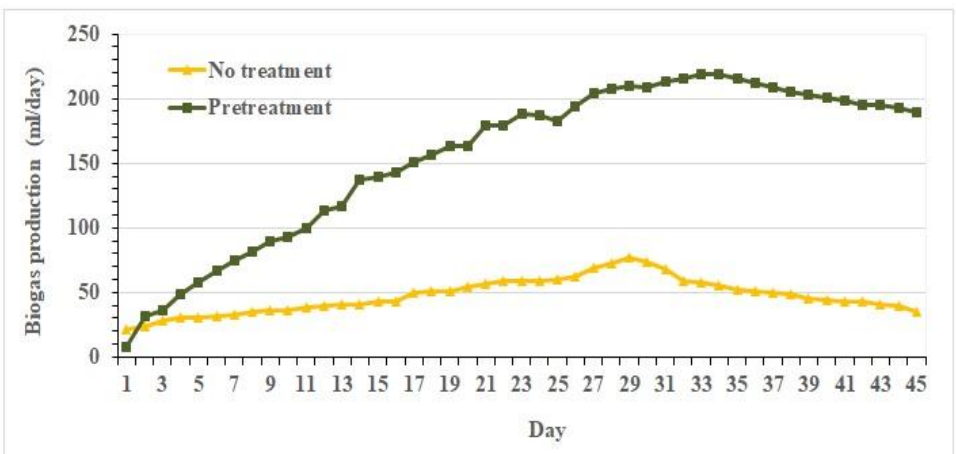

Figure-4.

Biogas production from the untreated and treated fermenter.

One approach to improving the economics of dairy digesters is to increase their biogas production rate by co-digesting manure with more degradable wastes, as long as such wastes are available near dairy farms and the farmland can use the wastes' nutrients and salts $[25,26]$. Furthermore, Co-digestion of different materials may improve anaerobic digestion by improving carbon and nutrient balance [27]. In addition, the digestion of multiple substrates in the same digester can result in positive synergism, and the additional nutrients can aid microbial growth. In this study, biogas production results were shown in Figure 4. The biogas production was highest about $230 \mathrm{ml} /$ day on the 35 day with pretreatment. The results reveled that pretreatments improves the biogas yield.

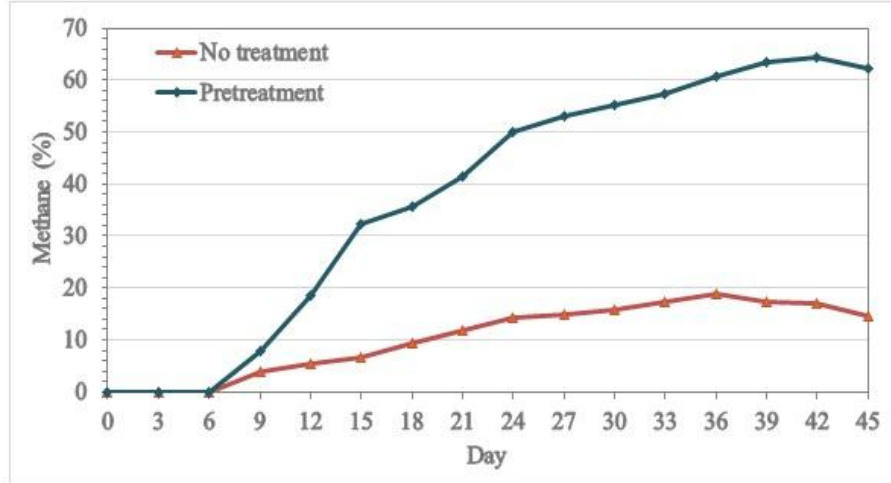

Figure-5.

Methane content of biogas from the untreated and treated fermenter.

The biogas system untreated and treated samples biogas total yield was 2139.14 and $6994.50 \mathrm{ml}$, respectively. In addition, it was shown that pretreated substrates were given the high-yield biogas (3 times higher) than the untreated fermenter. Furthermore, similarly, methane percentage of untreated (18.83\%, highest) and treated $(64.44 \%$, highest) fermentation results were shown in Figure 5. From the available literature, methane yield increased from 230 to 450 $\mathrm{L} / \mathrm{kgVS}$ added during mesophilic anaerobic co-digestion of cattle manure and fruit and vegetable wastes in a continuous stirred tank reactor at $35{ }^{\circ} \mathrm{C}$ and increasing the percentage of fruit and vegetable wastes from $20 \%$ to $50 \%$. Batch codigestion of cattle manure with molasses (50\% on a dry weight basis) at $35{ }^{\circ} \mathrm{C}$ increased biogas yield from 60 to 230 $\mathrm{L} / \mathrm{kgVS}$ added. However, their cattle manure biogas yield is lower than the yield reported by other researchers for dairy manure 
The purpose of this study was to look into the feasibility of incorporating source-slurry and energy crops biomass into digesters. Because of its high biodegradability, cow farm slurry is a desirable material to co-digestion with Napier grass. Besides total biogas and methane content, other biogas compositions (carbon dioxide, sulfur dioxide, oxygen, etc.) were not reported in the paper. In further scale-up studies, we will provide all the detailed information and biochemical analysis and degradation details. The higher calorific values (HCV) and lower calorific values (LCV) of pure methane were 39.82 and $35.87 \mathrm{MJ} / \mathrm{m}^{3}$. HCV and LCV of produced biogas were determined according to the following formula:

$\mathrm{HCV}_{\text {biogas }}=0.3989 \times \mathrm{MC}=0.0213\left(\mathrm{R}^{2}=1\right) \quad$ Eq. $(1)$.

$\mathrm{LCV}_{\text {biogas }}=0.3593 \times \mathrm{MC}=0.0192\left(\mathrm{R}^{2}=1\right) \quad$ Eq. $(2)$.

where MC is the methane content in biogas (\%). The biogas from the co-digestion of Napier grass and cow farm slurry containing the $\mathrm{HCV}$ was $25.69 \mathrm{MJ} / \mathrm{m}^{3}$ and $\mathrm{LCV}$ was $23.14 \mathrm{MJ} / \mathrm{m}^{3}$. Thus, it was much higher than biogas production from traditional AD [29-31] accordingly, this study verified that high-calorific biogas was obtained in this study system. We need to evaluate fuel quality, obtain biomass sources for analysis, and fuel quality research in general and from various sources a priority to meet our country's energy requirements. As long as biomass-based energy helps reduce deforestation, net greenhouse gas emissions and farm chemical runoff, it is acceptable. Napier grass with cow farm slurry could also be a good natural gas substitute. However, in this case, the durability of the gas output is insufficient. Therefore, more waste material combinations must be investigated, with Napier grass and/or cow farm slurry, in particular, acting as an accelerator. Improved results are thought to be possible with appropriate waste material combinations and proper environmental adjustments.

\section{Conclusion}

Anaerobic digestion is a waste management strategy that eliminates waste while producing biogas. Biogas is a type of renewable energy that is primarily composed of methane and carbon dioxide. This is suitable for use in transportation, energy generation, and cooking. Keeping key parameters within the desired range would improve biogas production as well. The availability of information on various biomass waste components is critical for the efficient implementation of anaerobic digestion. This study determined the production of biogas and methane yields of treated Napier grass and cow farm slurry using an anaerobic batch digester at $35( \pm 2)^{\circ} \mathrm{C}$. All the batch digestion tests were performed for 45 days, which was determined to achieve the complete digestion of all the substrates studied, and methane content is reached $66.4 \%$. In many countries, biomethane as a source of energy may be a critical component of the transition to sustainability. This research may be helpful for various types of developing countries as well.

\section{References}

[1] K. Whangchai, W. Inta, Y. Unpaprom, P. Bhuyar, D. Adoonsook, and R. Ramaraj, "Comparative analysis of fresh and dry free-floating aquatic plant Pistia stratiotes via chemical pretreatment for second-generation (2G) bioethanol production," Bioresource Technology Reports, vol. 14, p. 100651, 2021. Available at: https://doi.org/10.1016/j.biteb.2021.100651.

[2] P. Khammee, Y. Unpaprom, C. Chaichompoo, P. Khonkaen, and R. Ramaraj, "Appropriateness of waste jasmine flower for bioethanol conversion with enzymatic hydrolysis: Sustainable development on green fuel production," 3 Biotech, vol. 11, pp. 1-13, 2021. Available at: 10.1007/s13205-021-02776-x.

[3] G. F. C. Mejica, Y. Unpaprom, and R. Ramaraj, "Fabrication and performance evaluation of dye-sensitized solar cell integrated with natural dye from Strobilanthes cusia under different counter-electrode materials," App. Nano, pp. 1-11, 2021. Available at: 10.1007/s13204-021-01853-0.

[4] H. T. T. Nong, K. Whangchai, Y. Unpaprom, C. Thararux, and R. Ramaraj, "Development of sustainable approaches for converting the agro-weeds Ludwigia hyssopifolia to biogas production," Biomass Conversion and Biorefinery, pp. 1-9, 2020. Available at: https://doi.org/10.1007/s13399-020-01083-4.

[5] H. T. T. Nong, Y. Unpaprom, K. Whangchai, S. Buochareon, and R. Ramaraj, "Assessment of the effects of anaerobic codigestion of water primrose and cow dung with swine manure on biogas yield and biodegradability," Biomass Conversion and Biorefinery, pp. 1-11, 2020. Available at: https://doi.org/10.1007/s13399-020-01115-z.

[6] G. Van Tran, Y. Unpaprom, and R. Ramaraj, "Methane productivity evaluation of an invasive wetland plant, common reed," Biomass Conversion and Biorefinery, pp. 1-7, 2019.

[7] Y. Unpaprom, T. Pimpimol, K. Whangchai, and R. Ramaraj, "Sustainability assessment of water hyacinth with swine dung for biogas production, methane enhancement, and biofertilizer," Biomass Conversion and Biorefinery, vol. 11, pp. 849-860, 2021. Available at: https://doi.org/10.1007/s13399-020-00850-7.

[8] H. Nong, Y. Unpaprom, C. Chaichompoo, and R. Ramaraj, "Biomethane potential of invasive aquatic weed water primrose," Global Journal of Engineering Sciences, vol. 5, pp. 1-5, 2020. Available at: https://doi.org/10.37516/global.j.sci.eng.2021.0025.

[9] G. Van Tran, Y. Unpaprom, and R. Ramaraj, "Effects of co-substrate concentrations on the anaerobic co-digestion of common reed and cow dung," AJARCDE| Asian Journal of Applied Research for Community Development and Empowerment, vol. 3, pp. 28-32, 2019. Available at: https://doi.org/10.29165/ajarcde.v3i1.20.

[10] J. Kaewdiew, R. Ramaraj, S. Koonaphapdeelert, and N. Dussadee, "Assessment of the biogas potential from agricultural waste in northern Thailand," Maejo International Journal of Energy and Environmental Communication, vol. 1, pp. 40-47, 2019.

[11] A. Wannapokin, R. Ramaraj, K. Whangchai, and Y. Unpaprom, "Potential improvement of biogas production from fallen teak leaves with co-digestion of microalgae," 3 Biotech, vol. 8, pp. 1-18, 2018. Available at: https://doi.org/10.1007/s13205-0181084-7.

[12] N. Dussadee, R. Ramaraj, and T. Cheunbarn, "Biotechnological application of sustainable biogas production through dry anaerobic digestion of Napier grass," 3 Biotech, vol. 7, pp. 1-9, 2017. Available at: https://doi.org/10.1007/s13205-017-0646-4. 
[13] B. Saha, P. M. Yunus, M. Khwairakpam, and A. S. Kalamdhad, "Biochemical methane potential trial of terrestrial weeds: Evolution of mono digestion and co-digestion on biogas production," Materials Science for Energy Technologies, vol. 3, pp. 748-755, 2020. Available at: https://doi.org/10.1016/j.mset.2020.09.003.

[14] M. H. Tsai, W. C. Lee, W. C. Kuan, S. Sirisansaneeyakul, and A. Savarajara, "Evaluation of different pretreatments of Napier grass for enzymatic saccharification and ethanol production," Energy Science \& Engineering, vol. 6, pp. 683-692, 2018. Available at: https://doi.org/10.1002/ese3.243.

[15] APHA, Standard methods for the examination of water and wastewater, Centennial ed. Washington, DC: APHA, AWWA, WEF, 2005.

[16] P. Soest, J. Robertson, and B. Lewis, "Symposium: Carbohydrate methodology, metabolism and nutritional implications. In dairy cattle. Methods for dietary fiber, neutral detergent fiber and non starch polysaccharides in relation to animal nutrition," $J$ Dairy Sci, vol. 74, pp. 3583-3597, 1991. Available at: https://doi.org/10.3168/jds.s0022-0302(91)78551-2.

[17] A. T. Negawo, A. Teshome, A. Kumar, J. Hanson, and C. S. Jones, "Opportunities for Napier grass (Pennisetum purpureum) improvement using molecular genetics," Agronomy, vol. 7, p. 28, 2017.

[18] R. Ramaraj, Napier grass: Novel and valuable energy crop, 1st ed. Thailand: Chiang Mai, 2021.

[19] C. Font-Palma, "Methods for the treatment of cattle manure-a review," C, vol. 5, p. 27, 2019.

[20] H. Mashad and R. Zhang, "Biogas production from codigestion of dairy manures and food wastes," Bioresource Technology, vol. 101, pp. 421-428, 2010.

[21] R. Ramaraj and Y. Unpaprom, "Effect of temperature on the performance of biogas production from Duckweed," Chemistry Research Journal, vol. 1, pp. 58-66, 2016.

[22] R. Pantawong, A. Chuanchai, P. Thipbunrat, Y. Unpaprom, and R. Ramaraj, "Experimental investigation of biogas production from water lettuce," Pistia Stratiotes L. Emergent Life Sciences Research, vol. 1, pp. 14-46, 2015.

[23] R. Ramaraj, N. Dussadee, N. Whangchai, and Y. Unpaprom, "Microalgae biomass as an alternative substrate in biogas production," International Journal of Sustainable and Green Energy, vol. 4, pp. 13-19, 2015.

[24] R. Ramaraj, Y. Unpaprom, N. Whangchai, and N. Dussadee, "Culture of macroalgae Spirogyra ellipsospora for long-term experiments, stock maintenance and biogas production," Emergent Life Sciences Research, vol. 1, pp. 38-45, 2015.

[25] R. Ramaraj, Y. Unpaprom, and N. Dussadee, "Cultivation of green microalga, Chlorella vulgaris for biogas purification," IJNTR, vol. 3, pp. 117-122, 2016.

[26] R. Ramaraj and N. Dussadee, "Biological purification processes for biogas using algae cultures: A review," International Journal of Sustainable and Green Energy, vol. 4, pp. 20-32, 2015.

[27] N. Dussadee, Y. Unpaprom, and R. Ramaraj, "Grass silage for biogas production," Advances in Silage Production and Utilization, vol. 16, p. 153, 2016. Available at: https://doi.org/10.5772/64961.

[28] J. Mata-Alvarez, S. Macé, and P. Llabres, "Anaerobic digestion of organic solid wastes. An overview of research achievements and perspectives," Bioresource Technology, vol. 74, pp. 3-16, 2000. Available at: https://doi.org/10.1016/s09608524(00)00023-7.

[29] Y. Li, R. Zhang, Y. He, C. Zhang, X. Liu, C. Chen, and G. Liu, "Anaerobic co-digestion of chicken manure and corn stover in batch and continuously stirred tank reactor (CSTR)," Bioresource Technology, vol. 156, pp. 342-347, 2014. Available at: https://doi.org/10.1016/j.biortech.2014.01.054.

[30] A. Chuanchai and R. Ramaraj, "Sustainability assessment of biogas production from buffalo grass and dung: biogas purification and bio-fertilizer," 3 Biotech, vol. 8, pp. 1-11, 2018. Available at: https://doi.org/10.1007/s13205-018-1170-x.

[31] J. P. Chandrakant, N. Muhammad, P. Bhuyar, S. Krishnan, A. S. Abd Razak, A. Zularisam, and M. Nasrullah, "A review on the impact of conductive nanoparticles (CNPs) in anaerobic digestion: Applications and limitations," Environmental Technology \& Innovation, vol. 23, p. 101526, 2021. Available at: https://doi.org/10.1016/j.eti.2021.101526. 